\title{
Historein
}

Vol 14, No 1 (2014)

On the Edge of History and Philosophy

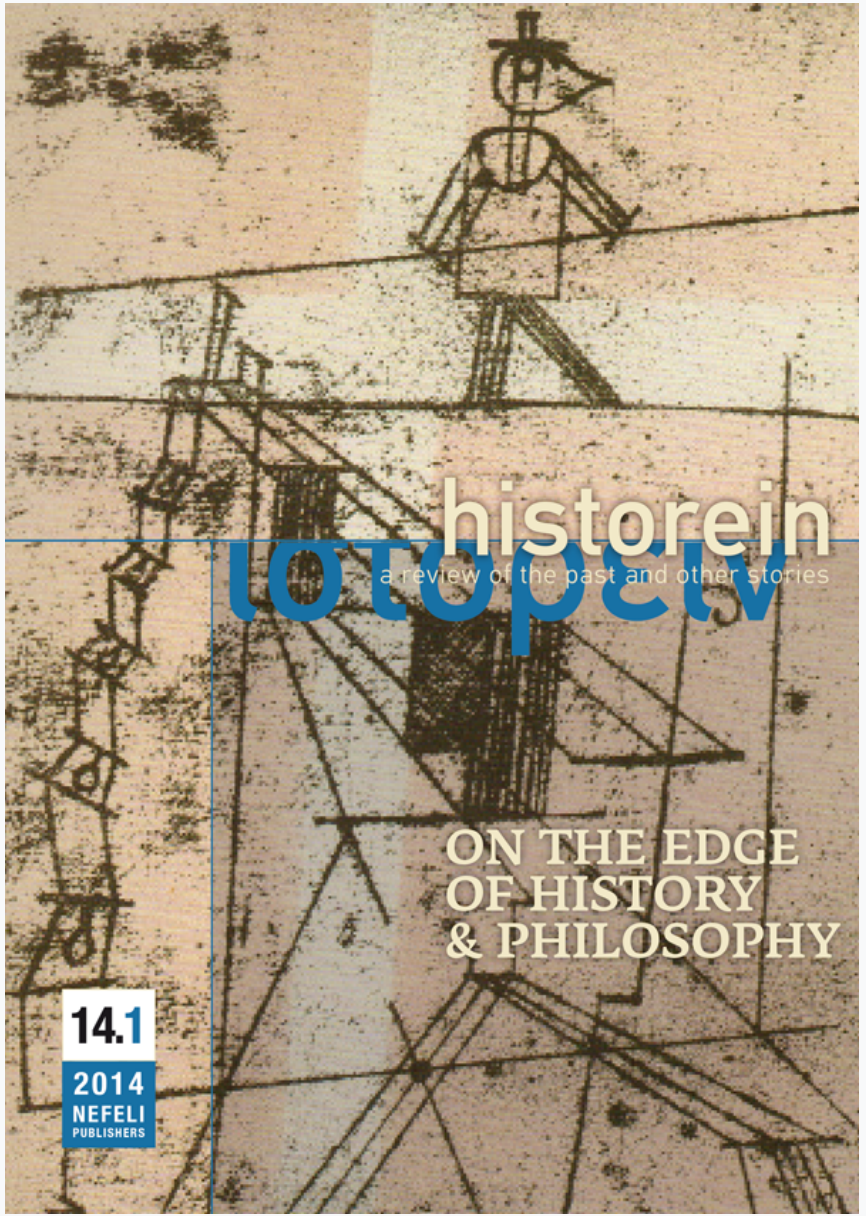

\section{Review of S. Trubeta's Physical Anthropology, Race and Eugenics in Greece (1880s-1970s)}

Manos Savvakis

doi: $10.12681 /$ historein.261

Copyright (C) 2014, Manos Savvakis

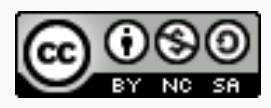

This work is licensed under a Creative Commons Attribution-NonCommercialShareAlike 4.0.

\section{To cite this article:}

Savvakis, M. (2014). Review of S. Trubeta's Physical Anthropology, Race and Eugenics in Greece (1880s-1970s). Historein, 14(1), 104-108. https://doi.org/10.12681/historein.261 


\section{BOOK REVIEWS}

\section{Sevasti Trubeta}

\section{Physical Anthropology, Race and Eugenics in Greece (1880s-1970s)}

\section{Brill: Leiden, 2013. 340 pp.}

\section{Manos Savvakis}

University of the Aegean

The historicity and the social impact of particular scientific fields, such as physical anthropology, are heavily controversial, ambiguous and extremely interesting at an epistemological, methodological and political - this is to say essentially practical - level. The conditions of physical anthropology's (re)production and transformation and the factors that assisted its popularity are always strongly interwoven with the social and cultural background of that particular historical period. At the same time, terms like race or eugenics, despite their descriptive, nevertheless questionable, power or scientific (in)validity, are present in a plethora of latent, in a Foucaultian sense, productive and labyrinthine forms. These terms function in that manner even though they have largely been expunged as problematic from public discourse.

This recently published book, promisingly entitled Physical Anthropology, Race and Eugenics in Greece (1880s-1970s), by Sevasti Trubeta, assistant professor of sociology at the University of the Aegean and an expert in this particular field, represents a unique theoretical, conceptual and methodological contribution to the critical understanding of a relevant underdeveloped and underexamined research field that is strongly connected, as the author claims, to the history and sociology of science as well as the history of medicine (7). Trubeta is interested in examining how a discipline that emerged from the natural sciences and medicine claimed it could influence society and how it was used to support and empower a national(istic) discourse.

The book reconstructs a historical period of almost a century (1880-1970), which is associated with serious economic, political, social, cultural and scientific transformations on all levels. The study energetically dives into the depths of anthropological science and brings out its controversies regarding the study of human life. Thus, the research questions explored are strongly interwoven with universal values and scientific claims, such as truth, and who has the right to express or address it, life and death, and their involvement within the institutional, cognitive and biographical affairs of human actors, as historically constituted subjects and culturally driven agents.

Clarifying her central methodological choice, Trubeta proposes a discourse-analytical approach to knowledge as a genuine research programme intended for practical implementation. This forms the appropriate means to capture both the symbolic and material dimensions of discursive formations and scientific settings (9). Following this methodological line, the study represents a conscious and systematically articulated attempt to put forward a synthetic analysis of a discourse that dominated the public sphere since the emergence of scientific naturalism, which was coupled with positivistic ideals, political pragmatism and a market-oriented political economy. The author, following Bourdieu and Foucault, seeks 
to examine from which sources, both symbolic and material, anthropology derived its scientific legitimacy, symbolic status and social interfusion in the particular case of Greece. At another level, she looks at the effects of power circulating in the scientific assumptions formulated by those involved in Greek anthropological discourse. The fundamental analytical basis is grounded on the inter-influence of three factors: the agency of the actors involved in this anthropological discourse, the production of anthropological knowledge, its (dis)contents and embedment in regimes of truth outside and inside the academic terrain (11).

This multileveled approach is evident in the organisation of the study, which includes three parts and nine well-balanced chapters that formulate the main research hypotheses formulated above. The books opens with an explanatory introduction that frames the overall research project, addresses the theoretical concepts applied and the preferred methodological choices. Besides, it summarises both the research questions and the scope of the study and outlines the structure of the book. The direct connection between science and politics, as the author contends, forms the bedrock for understanding the whole book and the sophisticated arguments it articulates.

The first part, which includes two chapters, examines the emergence of modern anthropology in Greece. Through a detailed analysis of the historical, intellectual and biographical trajectories of all the institutions and persons involved, the first chapter, entitled "Tracing the intellectual and epistemic sources of Greek anthropology", casts light on the intellectual and epistemic sources of Greek anthropolo- gy with respect to its elective affinity with Darwinian theories of evolution and notions of medical geography. The second chapter, "The emergence of anthropological institutions and professional scholarship", sufficiently investigates the relationship between the specialised form of scientific knowledge and the absence of professional groups of trained scientists, particularly anthropologists. The conclusion is that this connection ultimately failed for reasons concerning the peculiarity of the emergence of modern anthropology in Greece, an aspect that is analysed further on.

The second part, "Concepts of anthropology, institutional trajectories and scientific capital", focuses on (mis)conceptions of anthropology after its integration in academic institutions. The aim is to point out the professional inadequacy of anthropology, how it was integrated in medical faculties and the (paradoxical) claim raised by anthropologists that they were involved in investigating society. Thus, the third chapter, "Anthropology at the museum", methodically examines the alterations of the different notions of anthropology as reflected in the Anthropological Laboratory and Museum, founded in Athens in 1866. Greek anthropology managed to initially escape the narrow epistemological agenda of medical science, while still retaining a science restricted to the very limited scope of physical anthropology.

The fourth chapter, "Anthropology at the university chair", convincingly finds that there was a major contradiction between the initial scope of the first chair-holder, loannis Koumaris (1879-1970), and what actually happened. While the aim was to spread anthropological knowledge and methodology among 
the population, the teaching of this subject was reduced to the very restricted extent of physical anthropology. This particular failure to educate a new generation of anthropologists, which prevented the field's effective scientific reproduction, ultimately resulted to a dramatic decrease in Koumaris' scientific and social capital.

The fifth chapter examines the rise of the Greek Anthropological Society (Elliniki Anthropologiki Eteria), which eventually monopolised the various notions and conceptions of the field. This community, comprising well-known scholars from different disciplines (such as medicine, pathology, biology, the natural sciences and humanities), faced a constitutive ambiguity: rather than producing solely anthropological knowledge and research as a scientific institution, it became more a forum for presenting expertise derived from diverse research contexts. This was legitimised by the then widespread conceptualisation of anthropology as a holistic science and by the society's links to, or better willingness to connect with, the Greek royal family and, personally, to Prince Peter, himself a noted anthropologist.

The sixth chapter, " $A$ 'disinterested science' in wartime", implies that this effort to politicise anthropology was not accidental. On the contrary, it was clearly connected to the activities and the discourse of the society's members. Although the society proclaimed its political detachment and scientific neutrality, especially during the harsh years of the wartime occupation and the brutal civil war (1946-1949), it remained an influential political force. It understated the significance of Nazi crimes, and neutralised the "racial and Jewish question" by referring to scientific objectivity and Greek patriotic aspirations. These formed a nationalistic defence against the supposedly threatened Greek racial communality, which was, howev- er, protected by powerful traditional and religious bonds. Conclusively, the establishment of a connection between science (anthropol-

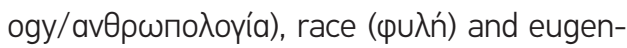
ics (euyovikń) is the main theme of the following part.

The third part, "Concepts of the Greek fili: communality in racial and eugenic terms", analyses the diverse and often provocative usages of the notion of fili in racial anthropological and eugenic discourses. The main argument is that, although the term is strongly connected or even identical to race, its semantics and metaphors provide it with a historically explained polysemy that endows it with a more complex dynamic and content.

The seventh chapter, "Race and Greek ancestry", investigates the racial anthropological conceptions of fili and argues that they were racial-anthropological in character and national in outlook. The basic argument raised is that the racial connotations of fili were transmitted and diffused in Greece echoing a peculiar controversy regarding the issue of "Greek continuity", an issue still relevant and present in the Greek public sphere. After the stabilisation of the nation-states in the Balkans, the discourse shifted from racial constancy to racial purity and national homogeneity. The rest of the chapter focuses on Koumaris' racial hygiene agenda in greater detail and claims that this was absolutely compatible with the prevailing racial hygiene priorities. The two sections in this chapter discuss the idea of the racial homogeneity of the Greek population and connect it to the "minority question"; namely the relation between Greece and neighbouring nation-states.

The eighth chapter, "The eugenic concept of fill", focuses on the particular character of eugenics in Greece and poses the question as to 
how eugenicists conceptualised the Greek collectivity, which they termed a fili. The remaining sections of the chapter discuss in greater detail issues like the medicalisation of society and the connection of poverty and social inequality with pathology and illness, morally blaming and legally prosecuting social groups that actually needed social assistance and solidarity. The central theoretical conclusion of this chapter, which is inspired by Foucault, is that fili is close to his notion of "race" with regard to a type of modern society characterised by the internal differentiation and inequality that runs along sociobiological lines and is transmitted by the discourses and practices of sexuality and reproduction.

The short, concluding chapter of the study reflects on the heritage of Greek anthropology, against the background of the decaying trajectory of its institutions. Furthermore, it raises the question as to whether this should be understood as a general failure of Greek anthropological discourse to find any relevance and connection to the realities of Greek society. Despite this particular failure, and this as well constitutes a Greek paradox, the heritage of this anthropological discourse is still present and effective in the political discourse of racial nationalism. One could at this point refer to the striking example of the Golden Dawn party and its allies. This essentially means that the lack of serious scientific, historical, anthropological and sociological criticism and strongly documented empirical studies, like the one under review, perpetuates the poisoning and blurring of both the public sphere and lifeworlds of active subjects in all social strata.

Trubeta's study represents a major contribution to a research field that is scientifically neglected, politically significant and urgent, and ethically controversial. The study is the first to interrogate racial and eugenic discourses in
Greece, robustly questioning their fundamental and secondary validity claims. It is also the first study of their dynamics in Greece without simply condemning their ideological influence. Rather, it continuously rebuts them. This is a unique contribution in that it points to new thematic and challenging research directions from the 1970s onwards. The emergence and the development of physical anthropology in the modern Greek state, from the viewpoint of the purported intention of its representatives that they were seeking to influence societal developments, is a topic that the author has already dealt with previously. However, in this study, she uses an astonishing plethora of new sources and "fresh" empirical material, ranging from historical archives to oral testimonies and autobiographies. The synthesis of different sources from a vast and impressive catalogue of primary material - including historical and university archives; university course calendars; minutes of meetings of professors at the medical faculty and university senate sessions; the publications, writings or testimonies of the main actors; working material of scientific associations; contemporary statements made in the press; the writings of Clon Stéphanos (1886-1915) and loannis Koumaris, including the latter's autobiography; archives in Berlin, scientific and social journals (such as the Greek Anthropological Society's proceedings and publications from the Greek Eugenics Society etc - has proven to be quite elaborate and effectively balanced.

The methodological originality and clarity regarding the use of the sources serves the research questions of the study, enriching its conceptual scope and analytical perspective. At this point, it is crucial to remember that the task of reconstructing a study from scratch, especially regarding the Greek context, is an extremely lonely, painful and difficult process. Her detailed research reveals not only the ob- 
vious character, but the latent parameters, of a multidimensional, sometimes "hidden" and widely unspoken histoire that still influences several aspects of Greek discourse, be it ethical, political, scientific or everyday conversation. Furthermore, the study of physical anthropology, eugenics and race provides the research community with some quite useful analytical tools to critically question the idea of being able to flawlessly define or easily design society along "pure" biological or medical lines.

To those living in a society that is experiencing an immense attack on social and personal rights at a variety of levels and which is facing the political uprising of the most reactionary, ultraconservative, dangerous and violent aspects of racial ideology and eugenic hygiene practices, this study offers a deep understanding of the foundations of this political rhetoric. As Walter Benjamin once wrote, "Truth is not a matter of exposure which destroys the secret, but a revelation that does justice to it".

\section{Christian Ingrao}

\section{Believe and Destroy: Intellectuals in the SS War Machine}

\section{Cambridge: Polity, 2013. xiv +399 pp}

\section{Anna Maria Droumpouki}

University of Athens

Is the intellectual elite capable of committing terrible crimes? Can an intellectual be part of a genocidal operation, a machinery of death? Why did a sample of 80 German academics, with high profiles and, in some cases, brilliant minds, join the repressive bodies of the Third Reich, especially the Security Service (SD) and the Nazi party's elite protection unit, the SS? How could they theorise and plan the extermination of 20 million individuals of allegedly "inferior" races? Most of them became members of the paramilitary death squads known as the Einsatzgruppen and participated in the slaughter of over a million people. The Einsatzgruppen were responsible for mass killings, primarily by shooting, and carried out operations that in cases lasted for days, such as the massacre at Babi Yar, one of the largest massacres in the history of the Holocaust (29-30September 1941). How can we interpret the mass participation of these people in the genocidal machinery of the Nazis?

In this book, Christian Ingrao tells the gripping story of 80 intellectuals who were young (barely in their 30s), clever and cultivated, and analyses the complicated mechanisms of their political commitment. This is a history of the executioners, not the victims. What is most interesting is the fact that Ingrao analyses Nazism as a system of beliefs. His explanation for the intellectual activism of these people is debatable; the interaction of knowledge, activism and levels of cultural sophistication 